\title{
SEJARAH PEMIKIRAN EKONOMI ISLAM
}

\author{
NUR EVI SUSANTI (90100118039) \\ Fakultas Ekonomi dan Bisnis Islam UIN Alauddin Makassar \\ e-mail:nurevisusanti@gmail.com
}

Sejarah permikiran ekonomi Islam telah ada sejak masa Rasulullah SAW. pada priode mekkah perekonomian masih sederhana baru ketika priode madinah menggunakan prinsip prinsip dasar pengelolaan ekonomi terhusus pada norma norma dan etika dalam masyarakat. ${ }^{1}$ Havis Aravik dalam bukunya yang berjudul "Sejarah Pemikiran Eknomi Islam Kontemporer" mengemukakan bahwa Islam telah membahas hal-hal megenai perekonomian atau muamalah jauh sebelum pemikiran-pemikiran Barat itu muncul. Hal ini ditandai dengan adanya ayat-ayat Al-Qur'an yang terbagi menjadi kurang lebih empat belas bagian, dimana semuanya membahas mengenai permasalahan ekonomi dan muamalah. ${ }^{2}$ Pemikiran terhadap ekonomi islam itu sendiri sudah ada bertepatan dengan diturunkannya Al- Qur'an pada masa Nabi, ialah pada akhir abad ke $6 \mathrm{M}$ hingga dengan permulaan abad ke $7 \mathrm{M}$. diturunkannya Al- Qur'an salah satunya agar dapat menyempurnakan ekonomi Islam sehingga tercipta kesejahteraan serta keadilan umat manusia. ${ }^{3}$

Pada masa periodesasi sejarah terdapat periode stagnansi atau transisi dimana pada masa itu kaum muslimin mengalami kemunduran. Pada masa ini bangsa Barat yang mulai lebih menghargai etika dan pengetahuan mengalami kebangkitan dan kemajuan, serta perlahan-lahan berbagai pemikiran dan teori mengenai perekonomian bermunculan. faktanya pada masa yang mereka klaim sebagai masa "great gap" ialah merupakan masa dimana banyak cendekiawan muslim yang lahir, seperti Abu Yusuf, Al-Ghazali, Al Farabi, Ibnu Sina dan masih banyak lagi ${ }^{4}$

Kejayaan ini dapat kita lihat pada masa Al-Ghazali, dimana dia dikenal sebagai seorang ilmuan yang konstruktif dan menjadi pusat perhatian baik bagi kaum muslimin maupun non-muslim. Pada masa Al-Ghazali ini pemerintah mendukung perkembangan ilmu pengetahuan secara besar-besaran dengan mendirikan berbagai pusat pendidikan sehingga mendorong berbagai dampak positif bagi kemajuan keilmuan dan perekonomian. Dalam periodesasi sejarahnya Al-Ghazali disebutkan berada pada masa periode kedua dalam sejarah pemikiran ekonomi Islam. Namun dalam masa ini pula korupsi dan dekadensi moral mulai menjamur. ${ }^{5}$

Sejarah pemikiran ekonomi Islam ini, fase kemunduran kaum musliminlah juga yang menjadi salah satu penyebab adanya penipisan sejarah bahkan terkesan dihilangkan terhadap kontribusi dunia islam terhadap perkembangan pemikiran ekonomi dengan adanya tesis Great Gap Analysis oleh Joseph Schumpeter tersebut. Belum lagi pendapat Joseph Schumpeter ini menurut

\footnotetext{
${ }^{1}$ Fauzan, I. "The The Tingking Of Islamic Economy In Muhammad Prophet Era (Pemikiran Ekonomi Islam Pada Masa Nabi Muhammad)”. Risalah, Jurnal Pendidikan Dan Studi Islam, 5(12 Maret), Tahun 2019, hlm 51-61.

${ }^{2}$ Havis Aravik, "Sejarah Pemikiran Ekonomi Islam Kontemporer” (Depok: Kencana, 2017) , hal. 1,2

${ }^{3}$ Helim, A., \& Fauzi, I, "Sejarah Pemikiran Ekonomi Islam (Masa Rasulullah Sampai Masa Kontemporer)” Tahun 2019.

4 Ali Rama, Schumpeterian 'Great Gap' Thesis And Medieval Islamic Economic Thought: Interlink Between Greeks, Medieval Islamic Scholars And European Scholastics, Al-Maslahah - Volume 13. No. 1. 2017. hal.27

${ }^{5}$ Sirajuddin, Konsep Pemikiran Ekonomi Al-Ghazali, Laa Maisyir, Volume 3, Nomor 1, Juni 2016, hal.47
} 
Ghazanfar telah menjadi layaknya bagian dari tradisi yang diterima dan tercermin dalam hampir setiap literature yang relevan dengan pembahasan ini. ${ }^{6}$

\section{DAFTAR PUSTAKA}

Ali Rama, Schumpeterian 'Great Gap' Thesis And Medieval Islamic Economic Thought: Interlink Between Greeks, Medieval Islamic Scholars And European Scholastics, Al-Maslahah - Volume 13. No. 1. 2017. hal. 27

Fauzan, I. "The The Tingking Of Islamic Economy In Muhammad Prophet Era (Pemikiran Ekonomi Islam Pada Masa Nabi Muhammad)". Risalah, Jurnal Pendidikan Dan Studi Islam, 5 (12 Maret), Tahun 2019, hlm 51-61.

Havis Aravik, "Sejarah Pemikiran Ekonomi Islam Kontemporer" (Depok: Kencana, 2017), hal. 1,2

Helim, A., \& Fauzi, I, "Sejarah Pemikiran Ekonomi Islam (Masa Rasulullah Sampai Masa Kontemporer)" Tahun 2019.

Sirajuddin, Konsep Pemikiran Ekonomi Al-Ghazali, Laa Maisyir, Volume 3, Nomor 1, Juni 2016, hal.47

${ }^{6}$ Ali Rama, Schumpeterian 'Great Gap' Thesis And Medieval Islamic Economic Thought: Interlink Between Greeks, Medieval Islamic Scholars And European Scholastics, Al-Maslahah - Volume 13. No. 1. 2017. hal.27 